\title{
Waldenström's macroglobulinaemia treated with cylophosphamide and chlorambucil
}

\author{
R. M. BUCKLE, G. C. JENKINS, AND G. L. MILLS \\ From St. Bartholomew's Hospital, North Middlesex Hospital, \\ and the Courtauld Institute of Biochemistry, Middlesex Hospital, London
}

SYNOPSIS A case of primary macroglobulinaemia of Waldenström is described in which prolonged treatment with the alkylating agents of cyclophosphamide and chlorambucil led to a sustained reduction in the concentration of circulating macroglobulin together with a concurrent improvement in the patient's symptoms.

The term 'macroglobulinaemia' was first introduced by Waldenström (1944) to describe a syndrome characterized by the presence of large quantities of circulating globulins of high molecular weight. Small amounts of macroglobulin may be found in normal plasma, but for diagnosis of the pathological state, macroglobulins, with a sedimentation value of $S_{20}{ }_{w} 16$ or more, should constitute at least $10 \%$ of the total plasma proteins (Martin, 1960). Macroglobulins may sometimes occur as an associated feature of diseases such as chronic lymphatic leukaemia and lymphosarcoma. But in some patients no such disease can be found, and these constitute primary or essential macroglobulinaemia of Waldenström. Irrespective of its exact aetiological basis, the well-defined abnormality of the serum proteins and the generally recognizable clinical picture make it useful to accept macroglobulinaemia as a disease entity; for many of the clinical features, as for example, the abnormal bleeding tendency, the development of retinopathy, heart failure, and the neurological manifestations, would appear to be the consequence of the high concentration of circulating globulins (Kappeler, Krebs, and Riva, 1958; MacKay 1959; Ritzmann, Thurm, Truax, and Levin, 1960b).

Response to treatment of Waldenström's macroglobulinaemia is often disappointing. Steroids and A.C.T.H. produce transient benefit (Glenchur, Zinneman, and Briggs, 1958; MacKay, 1959; Ritzmann et al., 1960b). Whereas experience with cytotoxic agents has been conflicting, early reports suggested that alkylating agents had little effect (Glenchur et al., 1958; Kappeler et al., 1958; Wintrobe, 1961), although recently, a response to chlorambucil has been recorded (Bayrd, 1961; Clatanoff and Meyer, 1963). This paper describes a

Received for publication 14 July 1965. further case of Waldenström's macroglobulinaemia successfully treated with long-term cytotoxic therapy.

\section{CLINICAL DETAILS}

A 50-year-old married woman was admitted to hospital complaining of weakness, lassitude, and swollen glands. During the preceding six months she had noticed swelling of the glands in her neck and had become progressively more weak and tired. In the last three months she had noticed increasing shortness of breath and palpitations on exertion. Her appetite had become impaired and she had lost one stone in weight. In addition, she bruised more easily and had had four small haemoptyses in the last year.

On examination, she was anaemic and there were scattered bruises on the arms and legs. The cervical and supraclavicular lymph glands were slightly enlarged, but there was no lymphadenopathy elsewhere. The liver was palpable $2 \mathrm{~cm}$. below the costal margin but the spleen could not be felt. The ocular fundi showed distension and tortuosity of the retinal veins, but no haemorrhages could be seen. Examination was otherwise normal.

INVESTIGATION The haemoglobin concentration was $50 \%(7.4 \mathrm{~g} . / 100 \mathrm{ml}$. $)$, the red cells numbered 3.0 millions/ c.mm. and the indices were normal, but marked rouleaux formation was present. The white cell count was 3,700/ c.mm. (polymorphonuclear leucocytes $36 \%$, lymphocytes $56 \%$, and monocytes $7 \%$ ); no immature cells were present. The platelet count was $200,000 / \mathrm{c} . \mathrm{mm}$. The erythrocyte sedimentation rate was $160 \mathrm{~mm}$. in the first hour (Westergren). The direct antiglobulin (Coombs) test was negative, the prothrombin time was $50 \%$ of normal (15 sec.), and the bleeding and clotting times were within normal limits. The plasma protein concentration was $7 \cdot 5 \mathrm{~g} . / 100 \mathrm{ml}$., albumin $3 \cdot 1$ and globulin $4 \cdot 4 \mathrm{~g} . / 100$ $\mathrm{ml}$. Paper electrophoresis showed an intense, well-defined band in the gamma globulin region. Quantitation of this component showed it to comprise $30 \%$ of the total plasma protein and to amount to a concentration of 


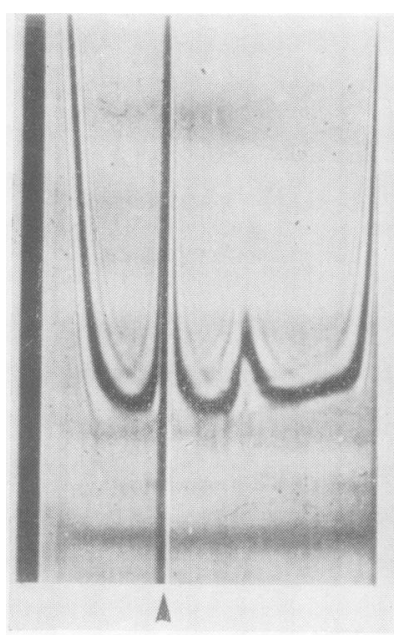

a

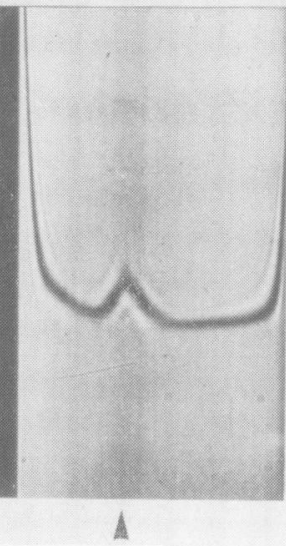

b

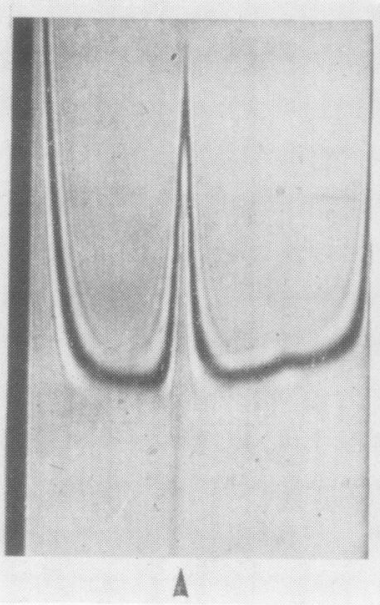

c

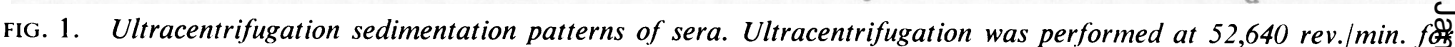
$30 \mathrm{~min}$. at $26^{\circ}$; phase plate angle $50^{\circ}$. Migration is from left to right. In each case $\boldsymbol{\Delta}$ indicates the position of the macres globulin peak.

(a) before treatment; (b) during treatment with cyclophosphamide (150 $\mathrm{mg} . /$ dav $) ;(c)$ at the end of maintenance treatment with cyclophosphamide; $(d)$ during treatment with chlorambucil.

$2.0 \mathrm{~g} . / 100 \mathrm{ml}$. The Sia test was positive. The urine did not contain any Bence Jones protein, but a small quantity of albumin was demonstrated on electrophoresis. Radiographs of the chest showed enlargement of the right hilum and tomography demonstrated this to be glandular in origin; the sputum did not contain any malignant cells. Radiographs of the skeleton were normal. Sternal marrow aspirate showed that $65 \%$ of the white cell series consisted of small lymphocytes, but no excess plasma cells were seen. Biopsy of a cervical gland showed some infiltration with lymphocytes and plasma cells. Ultra-centrifugation of the serum demonstrated the presence of macroglobulin of $S_{20} w 17 \cdot 1$ Svedberg units in a concentration of 1.8 g. $/ 100 \mathrm{ml}$. and comprising $26.8 \%$ of the total serum proteins (Fig. Ia).

TREATMENT AND PROGRESS The patient was transfused with 8 pints of blood. Treatment was started with penicillamine ( $\beta \beta$-dimethyl cysteine) $0.9 \mathrm{~g}$. increasing to $1.8 \mathrm{~g}$./day (as four divided doses) for three weeks. This had no effect on the clinical state. There was no appreciable change in the serum proteins (Fig. 2), nor in the electrophoretic pattern. The Sia test remained positive and ultracentrifugation showed no reduction in the quantity of circulating macroglobulin.

Cyclophosphamide was then given in a dosage of $50 \mathrm{mg}$. three times a day. A further transfusion was required during the first few weeks of treatment, but subsequently the haemoglobin was maintained at a value of $60 \%$ or more, and no further transfusions have been required. The patient's general conditions improved and bruising became less marked. Examination of the ocular fundi showed the calibre and the shape of the veins to have returned to normal. The superficial lymph glands regressed in size and further chest radiographs showee the hilar mass to have disappeared. During this time, tho serum globulin fell to $2.7 \mathrm{~g} . / 100 \mathrm{ml}$. and the Sia te became negative. Electrophoresis showed a progressive reduction in the quantity of the abnormal protein and ultracentrifugation showed the concentration of macro globulin $\left(S_{\Sigma 0} w 19.9\right)$ to have fallen to $0.22 \mathrm{~g} . / 100 \mathrm{~m} \frac{\mathrm{g}}{\mathrm{g}}$ (Fig. 1b).

Subsequently, a fall in the peripheral white cell coun necessitated reduction in the dosage of cyclophosphamide to $100 \mathrm{mg}$./day. No change occurred in the total cons centration of serum globulin, but ultracentrifugatiog showed a rise in the concentration of macroglobulin to $0.82 \mathrm{~g}$. $/ 100 \mathrm{ml}$., a value which comprised $11.9 \%$ of the total serum protein (Fig. 1c).

After six months' treatment, the patient noticed thas her hair was beginning to fall out; cyclophosphamide wa의 therefore stopped and chlorambucil substituted, in dosage of 6 to $10 \mathrm{mg}$./day, later being reduced to maintenance level of 2 to $4 \mathrm{mg}$./day. During the last $1 \frac{1 \mathrm{\pi}}{4}$ months' of treatment with chlorambucil the serungr globulin has remained between 2.2 and $1.5 \mathrm{~g} . / 100 \mathrm{mh}$ (Fig. 2). The Sia test has remained negative, and ultrar centrifugation shows the concentration of circulating macroglobulin of $S_{20}$ w $17 \cdot 2$ to be reduced to a value of $0.39 \mathrm{~g} . / 100 \mathrm{ml}$. $(6.2 \%$ of the total serum protein), an amount equal to one-sixth of the initial value (Fig. 1d) The patient's initial clinical improvement has beew maintained; the fundi have remained normal, there haso been no recurrence of lymphadenopathy and no abnorma $\overline{5}$ bleeding. The haemoglobin has remained above $60 \%$ an no further transfusions have been required. During the्ष whole course of treatment the patient's general healtip has been satisfactory and there has been complete relie 

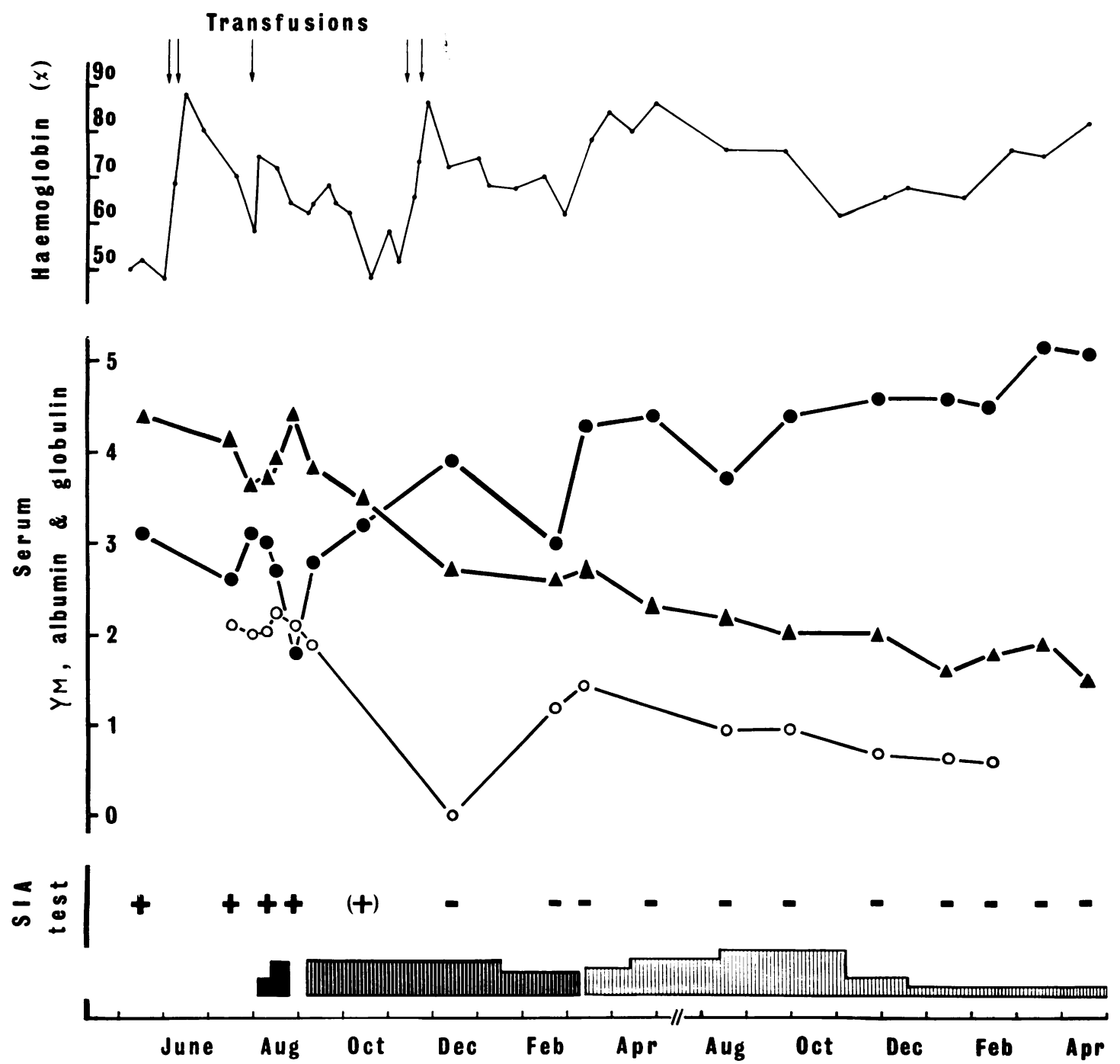

FIG. 2. Response of patient to penicillamine, cyclophosphamide and chlorambucil. $\bigcirc-$ serum albumin (g./100 ml.); $\Delta-\Delta$ serum globulin $(\mathrm{g} .1100 \mathrm{ml}.) ; \bigcirc — \bigcirc$ serum macroglobulin $(\mathrm{g} . / 100 \mathrm{ml}$.$) . Sia test +$ strongly positive, $(+)$ weakly positive, - negative. - penicillamine; ||||| cyclophosphamide; ||||| chlorambucil.

of symptoms. In addition to performing her normal household duties, she has continued to go out to work.

\section{DISCUSSION}

The high concentration of circulating macroglobulin is thought to be responsible for some of the clinical manifestations of the syndrome (MacKay, Eriksen, Motulsky, and Volwiler, 1956; Kappeler et al., 1958; MacKay, 1959), for the disturbance of blood clotting and interference with normal capillary and platelet function may predispose to bleeding, whilst the increased viscosity of the plasma may contribute to the development of heart failure and be responsible for the occurrence of retinal changes (Spalter, 1959). Cellular infiltration and deposition of abnormal protein in the perivascular spaces may account for the neurological disturbances that occur (Logothetis, Silverstein, and Coe, 1960). Treatment should therefore aim at reducing the concentration of circulating macroglobulins.

Removal of the abnormal proteins by plasmapheresis or exchange transfusion may be a useful emergency procedure (Schwab and Fahey, 1960; 
Conway and Walker, 1962). But the practical value of such treatment is limited, for the improvement is only temporary and the concentration of circulating macroglobulins returns to its former level within two to three weeks (Skoog, Adams, and Coburn, 1962).

Depolymerization of the macroglobulins with a consequent reduction in the viscosity of the plasma can be achieved in vitro by the addition of thiols of low molecular weight such as mercaptoethanol or $\beta \beta$-dimethyl cysteine (Deutsch and Morton, 1958; Glenchur et al., 1958), whilst on occasion, reduction of circulating macroglobulin has also been achieved in patients given penicillamine ( $\beta \beta$-dimethyl cysteine) by mouth (Bloch, Prasad, Ananstasi, and Briggs, 1960; Ritzmann, Coleman, and Levin, 1960a). However, Conway and Walker (1962) were unable to detect any such effect, nor was any seen in the present case. The Sia test remained positive, the level of the serum proteins remained unaltered, and ultracentrifugation showed no appreciable change in the quantity of circulating macroglobulins.

Numerous therapeutic agents have been tried in an attempt to reduce the rate of synthesis of the abnormal macroglobulins. Steroids and A.C.T.H. usually have a transient if any effect (Glenchur et al., 1958; MacKay, 1959; Ritzmann et al., 1960b; Kok, Whitmore, and Ainsworth, 1963), although a more prolonged improvement has been recorded (Pitney, O'Sullivan, and Owen, 1958; Fairley, 1963). Likewise, $x$-irradiation and $\mathrm{P}_{32}$ therapy are of limited value (MacKay et al., 1956). The results of treatment with cytotoxic agents have been conflicting. Early studies suggested that alkylating agents had little effect (Kappeler et al., 1958; Glenchur et al., 1958; Ritzmann, et al. 1960b; Wintrobe, 1961), but a reduction of macroglobulin following prolonged treatment with chlorambucil has been reported by Bayrd (1961) and more recently by Clatanoff and Meyer (1963). A similar response was found in the present patient with cyclophosphamide and later with chlorambucil given over a total period of 20 months. The concentration of serum globulin fell to normal and the Sia test became negative. Electrophoretic studies showed a marked fall in the concentration of the abnormal protein and this was confirmed by ultracentrifugation.

Concurrent with the sustained reduction of circulating macroglobulin there was a satisfactory symptomatic improvement in the patient's condition. The lymph glands regressed, bruising decreased in severity, no further haemoptyses occurred, and the appearance of the retinal veins returned to normal. Furthermore, the haemoglobin concentration has been maintained above $60 \%$. When anaemia develops in Waldenström's macroglobulinaemia, repeated transfusions are usually necessary, and our patie required 10 pints of blood during the two months before treatment was started, whereas during the last 20 months no transfusions have been necessary. $A$ similar reduction of transfusion requiremeris following treatment with chlorambucil was als observed by Clatanoff and Meyer (1963).

Evidence suggests that macroglobulins arise from the abnormal synthetic activity of lymphocytoid cells (Zucker-Franklin, Franklin, and Cooper, 19621, and it is probable that macroglobulinaemia should be regarded as a syndrome rather than as a distinet disease entity (Martin, 1960). Macroglobulinaenga may occur as an incidental feature in established cases of chronic lymphatic leukaemia, lymphosarcoma, or Hodgkin's disease, and treatment of the primaiy disorder with alkylating agents may cause the cogcentration of macroglobulins to fall (MacKay et al. 1956; Fairley, 1963). On the other hand, in primary macroglobulinaemia of Waldenström the accumulotion of macroglobulins in the blood is the dominant feature of the disease, although reticulo-endothelial tissue may show a characteristic proliferation lymphocytoid and plasma-like cells (Zollinge, 1958; Kok et al., 1963). Waldenström's macreglobulinaemia may therefore be classified amongst the lymphoproliferative states (Hayhoe, 196형 Wintrobe, 1961), and like them, long-term treatme with alkylating agents, such as cyclophosphamife and chlorambucil, may result in a satisfactofy remission of the disease.

We wish to thank Dr. K. O. Black, under whose ca敢 this patient was admitted, for permission to publis details of the case, and Professor N. H. Martin for tis help in establishing the diagnosis and for reviewing the histological sections. We should further like to thank Mr. P. Cull and Mr. D. Tredinnick of the Department.of Medical Illustration, St. Bartholomew's Hospital, for preparing the charts and photographs.

\section{REFERENCES}

Bayrd, E. D. (1961). Proc. Mayo Clin., 36, 135.

Bloch, H. S., Prasad, A., Ananstasi, A., and Briggs, D. R. (1960) J. Lab. clin. Med., 56, 212.

Clatanoff, D. V., and Meyer, O. O. (1963). J. Amer. med. Ass., 183, 40 .

Conway, N., and Walker, J. M. (1962). Brit. med. J., 2, 1296.

Deutsch, H. F., and Morton, J. I. (1958). J. biol. Chem., 231, 1107

Fairley, G. H. (1963). Proc. roy. Soc. Med., 56, 637.

Glenchur, H., Zinneman, H. H., and Briggs, D. R. (1958). Aw. intern. med., 48, 1055.

Hayhoe, F. G. J. (1960). Leukaemia. Research and Clinical Practi Churchill, London.

Kappeler, R., Krebs, A., and Riva, G. (1958). Helv. med. Acta, 25, 54. Kok, D'A., Whitmore, D. N., and Ainsworth, R. W. (1963). J. ctb. Path., 16, 351.

Logothetis, J., Silverstein, P., and Coe, J. (1960). Arch. Neurol. (Chi鸟) 3, 564.

MacKay, I. R. (1959). Aust. Ann. Med., 8, 158.

—, Eriksen, N., Motulsky, A. G., and Volwiler, W. (1956). Amer Med., 20, 564. 
Martin, N. H. (1960), Ouart. J. Med., 29, 179.

Pitney, W. R. O'Sullivan, W. J., and Owen, J. A. (1958). Brit. med. J., 2, 1508.

Ritzmann, S. E., Coleman, S. L., and Levin, W. C. (1960a). J. clin. Invest., 39, 1320.

-, Thurm, R. H., Truax, W. E., and Levin, W. C. (1960b). Arch. intern. Med., 105, 939.

Schwab, P. J., and Fahey, J. L. (1960). New Engl. J. Med., 263, 574.
Skoog, W. A., Adams, W. S., and Coburn, J. W. (1962), Blood, 19, 425. Spalter, H. F. (1959). Arch. Ophthal., 62, 868.

Waldenström, J. (1944). Acta med. scand., 117, 216.

Wintrobe, M. M. (1961). Clinical Hematology, 5th ed., Kimpton, London.

Zollinger, H. U. (1958). Helv. med. Acta, 25, 153.

Zucker-Franklin, D., Franklin, E. C., and Cooper, N. S. (1962). Blood, 20, 56.

\section{The November 1965 Issue}

\section{THE NOVEMBER 1965 ISSUE CONTAINS THE FOLLOWING PAPERS}

Obituary: Mary Barber M. R. POLLOCK

Embryonal sarcoma and embryonal rhabdomyosarcoma of the orbit NORMAN ASHTON and GWYN MORGAN

Squamous cell carcinoma of the body of the uterus HANNA BARNETT

Primary malignant lymphoma of the uterus H. Fox and J. R. S. MORE

Phycomycosis of the bronchus R. M. WINSTON

Heterotopic, non-functioning masses of nervous tissue in spina bifida cystica B. E. TOMLINSON

Ossifying pulmonary granulomatosis due to larvae of ascaris H. S. BAAR and J. GALINDO

Histological study of two cases of Coxsackie B virus pneumonia in children T. H. FLEWETT

Comparison of selective media for the isolation of salmonellae KELVIN ANDERSON and HELEN KENNEDY

Efficacy of different selective media for the isolation of salmonellae from faeces J. ZAJC-SATLER and S. BANIČ

Use of an improved cetrimide agar medium and other culture methods for Pseudomonas aeruginosa v. I. BROWN and E. J. L. LOWBURY

A non-starch-fermenting variant of Corynebacterium ulcerans W. H. H. JEBB and T. D. M. MARTIN

Plate method for the determination of the normal serum bacteriostatic activity against staphylococci J. CYBULSKA and J. JELJASZEWICZ

Some observations on magnesium in cerebrospinal fluid CHRISTOPHER PALLIS, IAIN MACINTYRE, and HAROLD ANSTALL

Lactic dehydrogenase isoenzymes in normal and pathological spinal fluids V. R. CUNNINGHAM, J. PHILLIPS, and E. J. FIELD

Alpha-amino nitrogen in cerebrospinal fluid and its alterations in meningitis, multiple sclerosis, and some other neurological disorders E. M. WILliams and D. M. MATTHEWS
Human urinary amylolytic enzymes in acute hepatitis C. FRANZINI and S. MODA

Micromethod for the determination of uric acid in biological fluids ROBERT G. MARTINEK

Quantitative aspects of the excretion of radioactive and microbiologically active material in urine after parenteral hydroxocobalamin J. F. ADAMS and ELIZABETH $\mathrm{H}$. KENNEDY

Effect of previous irradiation on the transformation of blood lymphocytes R. E. MILLARD

Defibrination syndrome with defective thrombinfibrinogen reaction reversible by protamine A. L. BLOOM and NORAH CAMPBELL

Rapid electrophoresis and quantitation of haemoglobins on cellulose acetate A. J. MARENGO-ROWE

Value of the Jirgl flocculation test in the diagnosis of jaundice D. P. ROSE and M. C. O'SHAUGHNESSY

Excretion of tryptophan metabolites in Friedreich's ataxia N. ROBINSON, G. CURZON, and P. THEAKER

Histochemical localization of copper in the gastrointestinal tract of the rat A. OLUFEMI WILLIAMS

Urea and oxalate inhibition of the serum lactate dehydrogenase PAULINE M. EMERSON and J. H. WILKINSON

Tests for rheumatoid factor after myocardial infarction R. A. THOMPSON

Pseudocholinesterase activity in thyroid disease J. C. THOMPSON and MARY WHITTAKER

Specific agglutination of tanned red cells coated with a globulin fraction of an antithyroid serum by saline extracts of thyroid glands IAN MACLEOD

Quantitative specific antigen determination using fluorescent antibody ROBERT L. NUTTER and PAUL WOODRUFF

Technical methods

Automatic determination of euglobulin lysis time J. D. CASH and E. LEASK

New reagent for the direct determination of serum cholesterol E. J. ALTESCU

Index to volume 18

Copies are still available and may be obtained from the PUBLISHING MANAGER, BRITISH MEDICAL ASSOCIATION, TAVISTOCK SQUARE, W.C.I.. price 18s. 6D. 